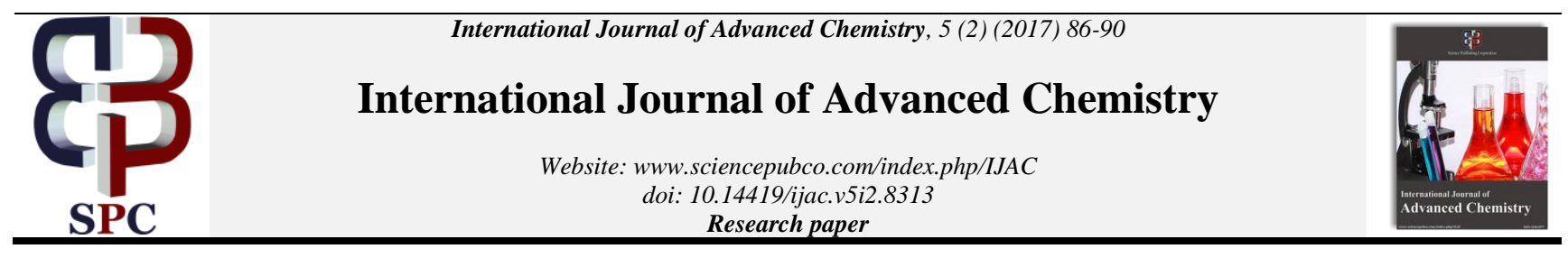

\title{
Spectrophotometric determination of paracetamol in drug formulations with 1 - naphthol
}

\author{
Raymond T. Iorhemen ${ }^{1} *$, Aondona M. Iorhemba ${ }^{1}$, Royalty Sambo ${ }^{1}$, Winifred U. Nande ${ }^{2}$ \\ ${ }^{1}$ Department of Chemistry, Ahmadu Bello University, Zaria - Nigeria \\ ${ }^{2}$ Department of Chemistry, University of Agriculture, Makurdi - Nigeria \\ *Corresponding author E-mail: iorhemenraymond@gmail.com
}

\begin{abstract}
Paracetamol with 1-Naphthol gave an azodye and the concentration of paracetamol was investigated spectrophotometrically. The dye

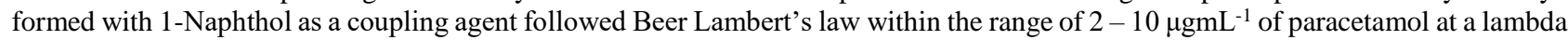
$\max \left(\lambda_{\max }\right)$ of $505 \mathrm{~nm}$. The molar absorptively of the azodye coupled with 1 -Naphthol was found to be $1.6973 \times 104 \mathrm{dm}^{3} \mathrm{~mol}^{-1} \mathrm{~cm}^{-1}, \mathrm{r}^{2}$ was 0.9974 . P value was found to be 0.013 at $95 \%$ confidence. LOD was $0.02 \mu \mathrm{gmL}^{-1}$ while LOQ was $0.10 \mu \mathrm{gmL}^{-1}$. The coupling agent has been applied successfully for the analysis of paracetamol in pharmaceutical preparations such as boska, ibex, mixagrip, norgesis and procold with the recovery of $101.27 \%, 98.98 \%, 99.47 \%, 98.28 \%$ and $101.6 \%$ respectively. The relative standard deviation of all the five samples ranged from $0 \%$ to $0.76 \%$. The method used in the present study may be applied to the determination of trace amount of paracetamol on clinical samples as it is simple, accurate and precise, and also reproducible.
\end{abstract}

Keywords: Determination of Paracetamol; Drug Formulations; Paracetamol; Paracetamol with 1-Naphthol; Spectrophotometry.

\section{Introduction}

Paracetamol [N-(4-hydroxy-phenyl) acetamide] is a drug that is commonly used for headaches and other minor aches and pains, including the management of more severe pains where it gives room for additional non-steroidal anti - inflammatory drugs to be used at lower doses, minimizing side effects (Chandra et al. 2013). Paracetamol, also known as acetaminophen (USA) is called by different trade names, including tylenol (derived from $\mathrm{N}$-acetyl-p-aminophenol), pannadol, pannadol extra (Jozwiak-Bebenista \& Nowak 2014) among many other names. It is a major ingredient in numerous cold and flu remedies, including procold and mixagrip. It has mild analgesic and anti-pyretic properties and is, along with acetylsalicylic acid, one of the most popular analgesic agents. At recommended doses, paracetamol is safe for use. However, at higher doses, it is reported to cause acute gastrointestinal problems. The synthesis of prostaglandin in the hypothalamus is blocked by paracetamol through the inhibition of cyclooxygenase -3 found throughout the brain and the spinal cord, hence the mechanism of paracetamol $(\mathrm{Vu}$ et al. 2014).

Paracetamol is prepared industrially by a one-step reduction acetamidation reaction which is mediated by thioacetate. In the laboratory, however, it is prepared by nitrating phenol with Sodium Nitrate, separating the desired P-nitrophenol from the ortho product and reducing nitro group with Sodium Borohydrate $\left(\mathrm{NaBH}_{4}\right)$. The resultant $\mathrm{P}$-aminophenol is then acetylated with acetic anhydride. A reaction in which phenol is highly activating. Thus the reaction only requires mild conditions. The equation of reaction is as stated below:

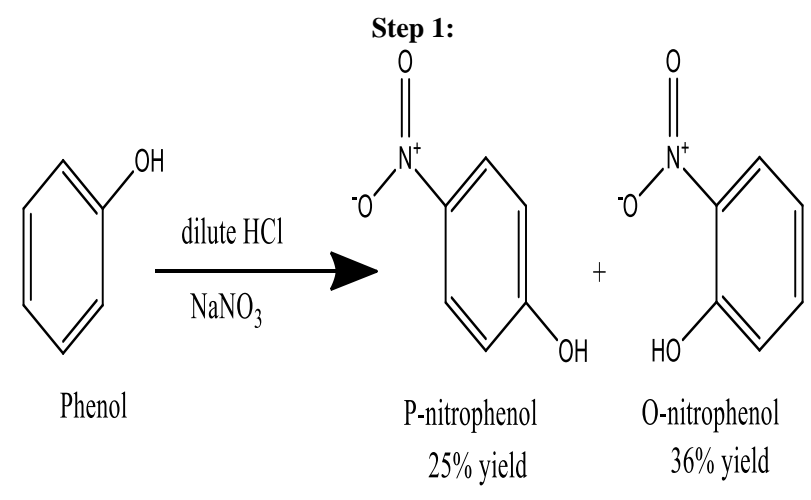

Step 2:<smiles>O=[N+]([O-])c1ccc(O)cc1</smiles>

P-nitrophenol

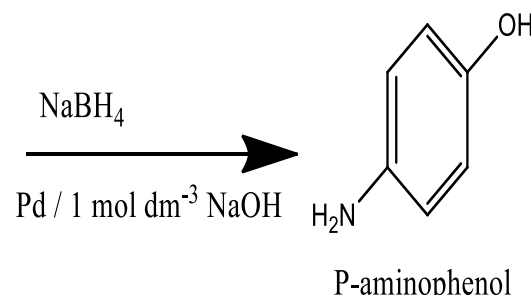

$74 \%$ yield 


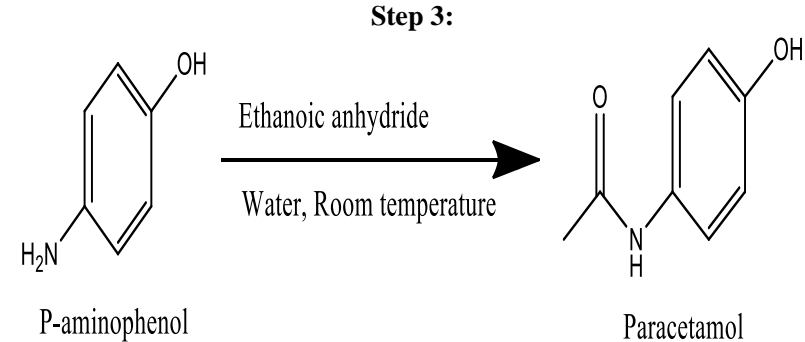

Fig. 1: Equation of Reaction for the Formation of Paracetamol.

Many methods have been used to assay paracetamol in pharmaceutical preparations. These include fluorometry, chemoluminescence (Easwaramoorthy et al. 2001), nuclear magnetic resonance - mass spectrometry (Shockcor et al. 1996), capillary electrophoresis (Heitmeier \& Blaschke 1999), titrimetry (EP 1997, Kumar \& Letha 1997, BP 1998, Usifoh et al. 2002), novel atomic absorption spectrometric methods (Issa et al. 2008), electrochemical methods (Silver et al. 2005), reversed phase high-performance liquid chromatography (Suzen et al. 1998, Chandra et al. 2013), spectrofluorometric method based on the oxidation with Sodium hypochlorite (Vilchez et al. 1995), spectrophotometric methods (Mohamed et al. 1997, Criado et al. 2000a, Criado et al. 2000b, Rodenas et al. 2000, Ruiz-Medina et al. 2000, Fatibello-Filho \& Vieira 2008, Pavan et al. 2012, Sharma et al., 2013) high-performance thin - layer chromatography (Dubey et al. 2012, et al. Yang 2012) and infra-red spectroscopy (Baptistao et al. 2011). Paracetamol can also be determined simultaneously with other drugs based on multivariate calibrations and ultraviolet spectrophotometric measurements (Marcelo \& Ronei 2004). Even without separation (Wefaa 2008). A chemometric approach using UV spectrophotometry has also been reported (Issa et al. 2011).

The Spectrophotometric determination of paracetamol is based on its hydrolysis to P-aminophenol (Buddha \& Raja 2009, Pavan et al 2012). The latter is reacted with specific reagents to produce a coloured substance which is monitored spectrophotometrically. The conversion of the hydrolyzed product to coloured species has been used to estimate paracetamol (Usifoh et al. 2002, Xu \& Li 2004, Buddha \& Raja 2009). The absorbance of that coloured species formed is measured in the visible region at appropriate wavelength. Hydrolysis of paracetamol gives $\mathrm{P}$ - aminophenol, which is then coupled with a coupling agent to yield an azodye - a famous Griess reaction which involves coupling and diazotization of aromatic amines. The reaction presented below:<smiles>CC(=O)Nc1ccc(O)cc1</smiles>

paracetamol

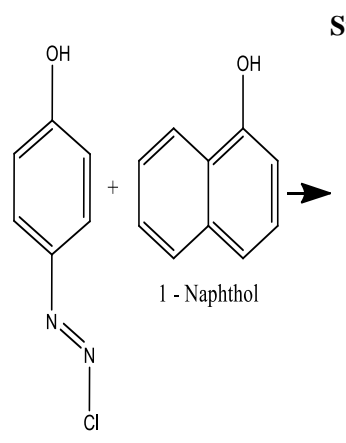

$(E)-4-$

(chlorodiazenyl)phenol

\section{Step 1:}

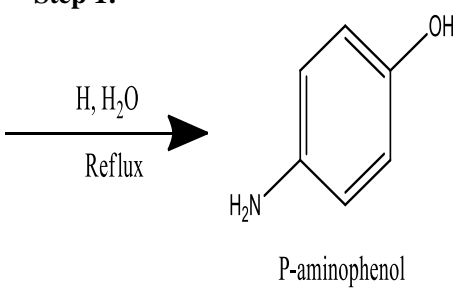

Step 2:

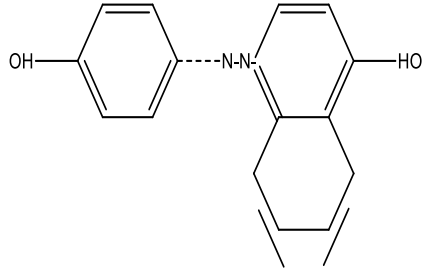

Azodye<smiles>Nc1ccc(O)cc1</smiles>

P-aminophenol

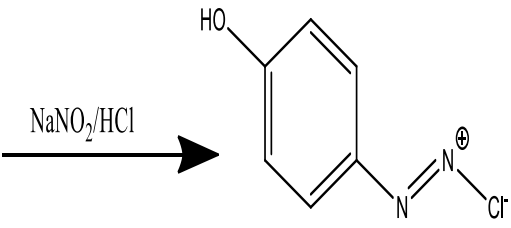

(E)-4-(chlorodiazenyl)phenol
Fig. 2: Reaction for the formation of an azodye with 1 - Naphthol.

A simple, rapid and reliable method to assay pure paracetamol and paracetamol in pharmaceutical formulations is presented. Reaction of the diazonium salt (P-aminophenol in dilute acid) with 1-Naphthol in $\mathrm{NaOH}$ as a coupling agent produces an azodye as shown above. The wavelength of maximum absorption is $505 \mathrm{~nm}$.

This work is aimed at developing a spectrophotometric method that will be precise and accurate in determining the concentration of paracetamol in pharmaceutical formulations. The choice of ultraviolet visible spectrophotometry is based on its availability and the quest to simplify analytical procedures using the readily available tools. This work is significant in improving on the quality control of drugs as the breakthrough will help to assay the accurate concentration of paracetamol in pharmaceutical formulations.

\section{Materials and method}

All reagents used were of analytical grade. A sample of pure paracetamol was obtained from ECWA Central Pharmacy limited, Jos - Nigeria.

Five samples known to contain paracetamol were obtained from the open market. These include: Boska (tablets manufactured by PT Dexa Medica and labeled to contain $500 \mathrm{mg}$ paracetamol per tablet), Ibex (capsules manufactured by Sanofi - Aventis and labeled to contain $325 \mathrm{mg}$ paracetamol per capsule), Procold (Concept Pharmaceuticals and labeled to contain $500 \mathrm{mg}$ paracetamol per tablet), Moxagrip (tablets manufactured by symmelics laboratories and labeled to contain $500 \mathrm{mg}$ paracetamol per tablet) and Norgesic (tablets manufactured by iNova Pharmaceuticals and labeled to contain $350 \mathrm{mg}$ paracetamol per tablet). The choice of these drugs was based on the fact that these are the most consumed and commonly available drugs.

The apparatus used to include:: Measuring cylinders, volumetric flasks, reflux condenser, pipette, magnetic bar, weighing balance, round bottom flask, retort stand, gallen camp magnetic stirrer thermostat hot plate, crucibles and Jen way 6300 spectrophotometer.

\section{Experimental}

\subsection{Preparation of reagents}

About $250 \mathrm{mg}$ of the pure paracetamol was accurately weighed out and refluxed with $20 \mathrm{~mL}$ of $4 \mathrm{M} \mathrm{HCl}$ and distilled water to prepare a standard solution. The resulting $\mathrm{P}$ - aminophenol was then diluted appropriately, and the required aliquots were taken to prepare the calibration curve.

To prepare a $4 \mathrm{M} \mathrm{HCl}$, a $21.8 \mathrm{~mL}$ of concentrated $\mathrm{HCl}$ was measured and transferred to a $200 \mathrm{~mL}$ volumetric flask containing $100 \mathrm{ml}$ distilled water.

A $0.1 \mathrm{~g} \mathrm{NaNO}_{3}$ was weighed and transferred to a $100 \mathrm{~mL}$ volumetric flask where distilled water was used to make up to mark to prepare $0.1 \% \mathrm{w} / \mathrm{v} \mathrm{NaNO}_{3}$.

To prepare a $0.5 \% \mathrm{v} / \mathrm{v}$ ammonium sulfamate, $\left(\mathrm{NH}_{4} \mathrm{SO}_{3} \mathrm{NH}_{2}\right)$, a 0.5 $\mathrm{mL} \mathrm{NH} \mathrm{SO}_{3} \mathrm{NH}_{2}$ was measured into a $100 \mathrm{~mL}$ volumetric flask and $99.5 \mathrm{~mL}$ distilled water added to it.

To prepare $0.5 \%$ w/v 1 - Naphthol, a 0.5 g 1 - Naphthol was weighed out and dissolved in $99.5 \mathrm{~mL}$ distilled water A $16 \mathrm{~g} \mathrm{NaOH}$ was weighed out and dissolved in $100 \mathrm{~mL}$ distilled water to prepare $4 \mathrm{M} \mathrm{NaOH}$. 
The five samples obtained were weighed and powdered. The amount of each of the powdered samples equivalent to $250 \mathrm{mg}$ was weighed out and refluxed with $20 \mathrm{~mL}$ of $4 \mathrm{M} \mathrm{HCl}$ and $30 \mathrm{~mL}$ distilled water for 30 minutes.

\subsection{Preparation of the calibration curve}

Solutions containing $2-10 \mu \mathrm{gmL}^{-1}$ of paracetamol equivalent were taken into $25 \mathrm{~mL}$ volumetric flasks. To this aliquot, $0.6 \mathrm{~mL}$ of $4 \mathrm{M}$ $\mathrm{HCl}$ and $1 \mathrm{~mL}$ of $0.1 \%$ Sodium Nitrite were added for diazotization. A $1 \mathrm{~mL}$ of ammonium sulfamate solution was added to each after 3 minutes to destroy excess nitrous acid and left for 2 minutes. Then, $1.5 \mathrm{~mL}$ of $0.5 \% \mathrm{w} / \mathrm{v}$ solution of Naphthol in $4 \mathrm{M} \mathrm{NaOH}$ was added as a coupling agent. The absorbance of this analyte was measured at a $\lambda_{\max }$ of $505 \mathrm{~nm}$. The absorbance obtained was used to prepare the calibration curve.

The same process was repeated for the samples and the absorbance was taken. The various absorbance were extrapolated on the calibration curve to get the various concentrations

\subsection{Limit of detection (LOD) and limit of quantification (LOQ)}

LOD and LOQ refer to the lowest concentration of the active substance that can be determined by a method (Islam et al. 2011. This was obtained by making serial dilutions of a standard solution of paracetamol from the stock and preparing it in replicates of three. The absorbance of these was measured and compared to that of the blank.

\subsection{Percentage recovery}

This was used to determine the accuracy of the proposed method at different concentration levels. The percentage recovery was then determined using the equation (Entidhar et al. 2013) below:

$\%$ Recovery $=[A] /[B] \times 100$

Where [A] is the sample concentration extrapolated from the calibration curve, $[\mathrm{B}]$ is the known concentration of the sample before taking the absorbance.

\subsection{Statistical analysis}

Pearson correlation analysis and significant testing at $95 \%$ were used to check the linearity of the calibration curve as well as the significant levels respectively. The precision of the new method was checked using the $\mathrm{F}$ - test.

\section{Result and discussion}

The maximum absorbance of the azodye formed in an alkaline medium with $10 \mu \mathrm{gmL}^{-1}$ of paracetamol in 1 - naphthol was observed at $505 \mathrm{~nm}$.

\subsection{Calibration curve}

Figure 3 below shows the plot of absorbance against concentration of paracetamol. It shows that the dye formed in the alkaline medium obeys Beer Lambert's law from $2-10 \mu \mathrm{gmL}^{-1}$ of paracetamol. The molar absorptivity was found to be $1.6973 \times 10^{4} \mathrm{dm}^{3} \mathrm{~mol}^{-1} \mathrm{~cm}^{-1}$.

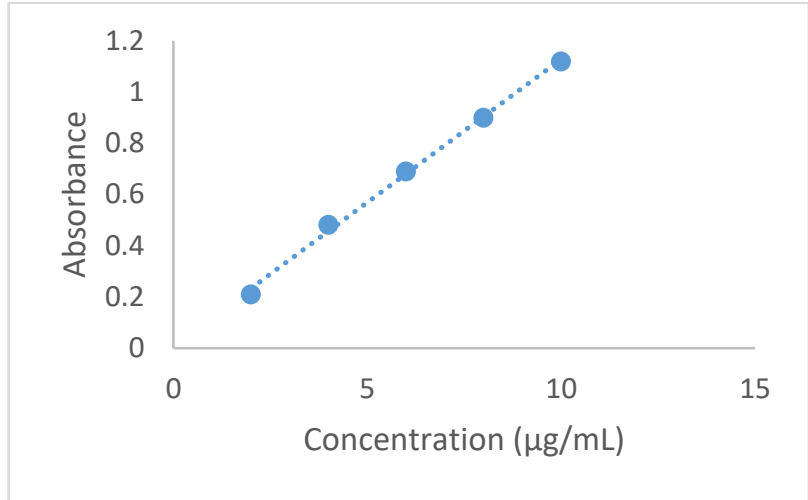

Fig. 3: Calibration Curve.

From the calibration curve above, the pearson correlation was found to be 0.9974 indicating a strong positive correlation between the absorbance and the concentration and also confirming the linearity of the curve, thus, rationalizing the provisions of Beer - Lambert Law. Such an out is typical of a simple, accurate and precise method. The calibration curve equation is represented by the equation below:

Absorbance $=0.01+0.1118[$ Paracetamol $]$

Significance test was also carried out for the calibration curve, and it showed that at $95 \%$ confidence, $P(\leq \alpha \leq 0.05)$ value was found to be 0.013 , it. Therefore, implies that there is a significant statistical difference in the mean of the absorbance and that of the concentration hence, there is a strong positive correlation between the calibration curve variables.

\subsection{Sample concentration}

The concentration of paracetamol was estimated for the five samples by extrapolation of their absorbance on the calibration curve so as to obtain the concentrations. The result is presented in figure 4 below:

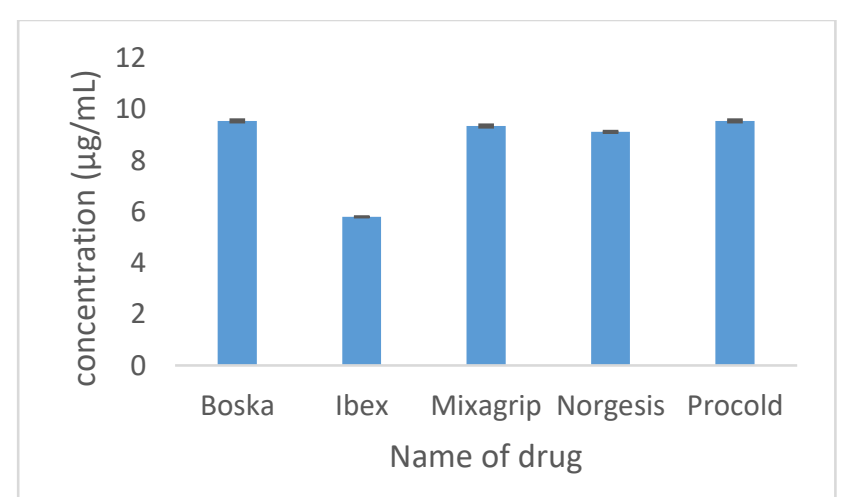

Fig. 4: Concentrations of the Samples As Extrapolated From the Calibration Curve.

\subsection{Sample recovery}

The concentration of paracetamol content in the samples and the concentration stated by the manufacturer is also presented by figure 5 below. From the chart, the estimation of the amount of paracetamol present in each sample based on the percentage yield agreed with similar work done by Suzen et al [14]. Even though Suzen's method was a chromatographic method. It can be seen from the above table that there was a very slight variation between the analyzed and specified amount of paracetamol present in each sample. This is a confirmation of the authenticity of the method used in this work. The slight variation observed might be due to the suspected presence of other aromatic amines present in the solution. The reason for this suspicion was based on the fact that other ingredients were added throughout the production. These added ingredients 
must probably have had a little interference with the compound ( $\mathrm{Pa}-$ racetamol) thereby hindering its determination by this method. The difference is quite negligible, which indicate that the possible interference had little or no significant effect on accuracy of the method. The presence of the substrates affected the dissolution of these drugs at the initial stage of this research.

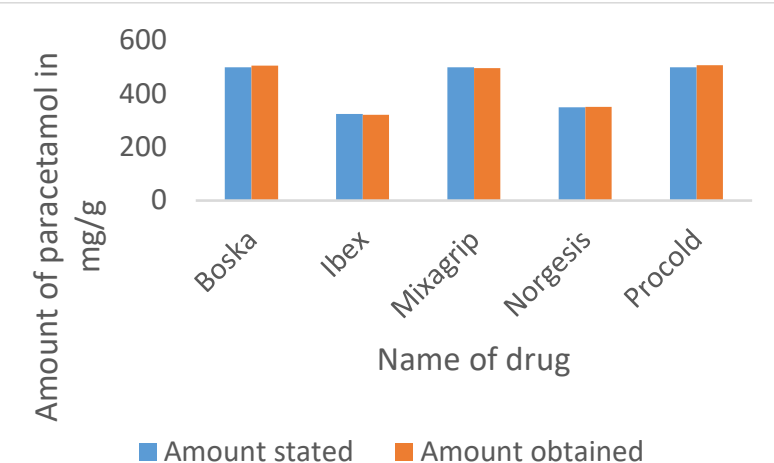

Fig. 5: Concentrations of the Samples Recovered by the Method and That Stated by the Manufacturer

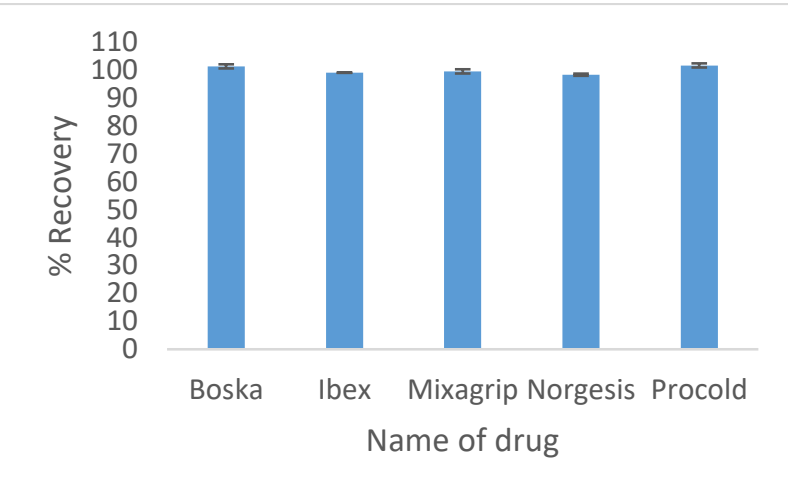

Fig. 6: Percentage Recovery.

The percentage recovery along with the relative standard deviation determined in the five replicates analyses as shown above shows a high accuracy of this method. The recovery ranged from $98.28 \%$ to $101.6 \%$ while the relative standard deviation of all the five samples ranged from $0 \%$ to $0.76 \%$. These values are also in agreement with similar work available in literature (Cekic et al. 2005).

\subsection{Limit of detection (LOD) and limit of quantification (LOQ)}

LOD and LOQ represent the concentration of the analyte that would yield signal to noise ratios of 3 for LOD and 10 for LOQ respectively [1]. The absorbance of these was measured and compared to that of the blank. The signal to noise ratio of 3:1 (LOD) and 10:1 (LOQ) was thus determined. The values were found to be 0.02 $\mu \mathrm{g} / \mathrm{mL}$ (LOD) and $0.11 \mu \mathrm{g} / \mathrm{mL}$ (LOQ). With the values for LOD and LOQ, the accuracy of the method used in the present study is further enhanced.

The $\mathrm{F}$ - test value was 0.9619 at $95 \%$ confidence, which is close to 1 , indicating that the null hypothesis which states that there is no significant difference between variances of the stated amount, and the recovered amount is true and is therefore accepted. This indicates the high precision of this method.

\section{Conclusion}

An investigation was made of a coupling agent - 1-Naphthol - to estimate paracetamol in pharmaceutical preparations using a simple and sensitive spectrophotometric method. The amount of paracetamol determined by this method was found to be in close agreement with the amount stated by the manufacturers.
The percentage recovery of paracetamol was found to range from $98.28 \%$ to $101.6 \%$ indicating that the five drugs were suitable to be administered for the prescribed purposes. The percentage recovery as well as the LOQ and LOD test show the high accuracy of the method used. The high precision was also shown by the relative standard deviation of the replicates. The stability of the azodye formed by this method lasted for 45 minutes. Therefore, the present method is simple, accurate and precise, and can be used for routine analyses of paracetamol in both raw materials and paracetamol tablets and capsules.

\section{Appendices}

\begin{tabular}{ll}
\multicolumn{2}{c}{ Appendix 1: Linearity Table } \\
\hline Parameter & Value \\
\hline $\mathrm{P}(0.05)$ & 0.0126 \\
Regression Equation & $\mathrm{Y}=0.1118 \mathrm{x}+0.01$ \\
Regression Coefficient $\left(\mathrm{r}^{2}\right)$ & 0.9974 \\
Limit of detection & $0.02 \mu \mathrm{g} / \mathrm{mL}$ \\
Limit of Quantification & $0.10 \mu \mathrm{g} / \mathrm{mL}$ \\
\hline
\end{tabular}

\begin{tabular}{|c|c|c|c|c|c|c|}
\hline \multicolumn{7}{|c|}{ Appendix 2: Recovery Table } \\
\hline $\begin{array}{l}\text { Name } \\
\text { of } \\
\text { drug }\end{array}$ & $\begin{array}{l}\text { Amount } \\
\text { added } \\
(\mu \mathrm{g} / \mathrm{mL} \\
)\end{array}$ & $\begin{array}{l}\text { Amount } \\
\text { obtained } \\
(\mu \mathrm{g} / \mathrm{mL})\end{array}$ & $\begin{array}{l}\% \text { Re- } \\
\text { cov- } \\
\text { ery }\end{array}$ & $\begin{array}{l}\mathrm{CV} \\
(\%)\end{array}$ & $\begin{array}{l}\text { Amoun } \\
\mathrm{t} \text { in } \\
\mathrm{mg} / \mathrm{g} \\
\text { added }\end{array}$ & $\begin{array}{l}\text { Amoun } \\
\mathrm{t} \mathrm{in} \\
\mathrm{mg} / \mathrm{g} \\
\text { recov- } \\
\text { ered }\end{array}$ \\
\hline $\begin{array}{l}\text { Bosk } \\
\text { a }\end{array}$ & 9.43 & $\begin{array}{l}9.55 \pm 0.0 \\
5\end{array}$ & $\begin{array}{l}101.2 \\
7\end{array}$ & $\begin{array}{l}0.7 \\
4\end{array}$ & 500 & 506 \\
\hline Ibex & 5.86 & $\begin{array}{l}5.80 \pm 0.0 \\
0\end{array}$ & 98.98 & 0 & 325 & 322 \\
\hline $\begin{array}{l}\text { Mixa- } \\
\text { grip }\end{array}$ & 9.40 & $\begin{array}{l}9.35 \pm 0.0 \\
5\end{array}$ & 99.47 & $\begin{array}{l}0.7 \\
6\end{array}$ & 500 & 497 \\
\hline $\begin{array}{l}\text { Nor- } \\
\text { gesis }\end{array}$ & 9.28 & $\begin{array}{l}9.12 \pm 0.0 \\
3\end{array}$ & 98.28 & $\begin{array}{l}0.3 \\
9\end{array}$ & 450 & 451 \\
\hline $\begin{array}{l}\text { Pro- } \\
\text { cold }\end{array}$ & 9.40 & $\begin{array}{l}9.55 \pm 0.0 \\
5\end{array}$ & $\begin{array}{l}101.6 \\
0\end{array}$ & $\begin{array}{l}0.7 \\
4 \\
\end{array}$ & 500 & 508 \\
\hline
\end{tabular}

\begin{tabular}{|c|c|c|c|c|}
\hline Sample & Manufacturer & $\begin{array}{l}\text { Manufacturer's } \\
\text { Specifications }\end{array}$ & $\begin{array}{l}\text { Amount } \\
(\mathrm{mg} / \mathrm{g})\end{array}$ & $\begin{array}{l}\text { Dosage } \\
\text { Form }\end{array}$ \\
\hline \multirow[t]{2}{*}{ Boska } & \multirow{2}{*}{$\begin{array}{l}\text { PT Dexa } \\
\text { Medica }\end{array}$} & Paracetamol & 500 & \multirow[t]{2}{*}{ Tablet } \\
\hline & & Caffeine & 30 & \\
\hline \multirow[t]{2}{*}{ Ibex } & \multirow[t]{2}{*}{$\begin{array}{l}\text { Sanofi - } \\
\text { Aventis }\end{array}$} & Paracetamol & 325 & \multirow[t]{2}{*}{$\begin{array}{l}\text { Cap- } \\
\text { sules }\end{array}$} \\
\hline & & $\begin{array}{l}\text { Caffeine } \\
\text { Ibuprofen }\end{array}$ & $\begin{array}{l}30 \\
200\end{array}$ & \\
\hline \multirow[t]{3}{*}{$\begin{array}{l}\text { Mixa- } \\
\text { grip }\end{array}$} & synmedics & Paracetamol & 500 & \multirow[t]{3}{*}{ Tablets } \\
\hline & Laboratories & Pseudoephedrine & 30 & \\
\hline & & $\begin{array}{l}\text { Chlorphenira- } \\
\text { mine Meleate }\end{array}$ & 2 & \\
\hline \multirow[t]{2}{*}{$\begin{array}{l}\text { Nor- } \\
\text { gesis } \\
\text { (Anorol) }\end{array}$} & $\begin{array}{l}\text { iNova Pharma- } \\
\text { ceuticals }\end{array}$ & Paracetamol & 450 & \multirow[t]{2}{*}{ Tablets } \\
\hline & & $\begin{array}{l}\text { Orphenadrine } \\
\text { Citrate }\end{array}$ & 5 & \\
\hline \multirow[t]{3}{*}{ Procold } & Concept & Paracetamol & 500 & \multirow[t]{3}{*}{ Tablets } \\
\hline & $\begin{array}{l}\text { Pharmaceuti- } \\
\text { cals }\end{array}$ & $\begin{array}{l}\text { Pseudoephedrine } \\
\mathrm{HCl}\end{array}$ & 30 & \\
\hline & Ltd & $\begin{array}{l}\text { Chlorphenira- } \\
\text { mine Meleate }\end{array}$ & 2 & \\
\hline
\end{tabular}

\section{References}

[1] Chandra R, Verma D, Sharma KD, Kumar S, Naushad Alam MD \& Singh S (2013), Comparative quantitative determination of paracetamol by RP-HPLC and UV Spectrophotometry from its formulated tablets. International Journal of Pharmacy and Pharmaceutical Sciences 5, 3 .

[2] Marta Jozwiak-Bebenista \& Jerzy z. Nowak (2014), Paracetamol: Mechanism of Action, Applications and Safety Concern. Acta Poloniae Pharmaceutica -Drug Research 71(1), 11-23. 
[3] Vu DH. Dong THL. Nguyen HT \& Hue MTN (2014), UV Spectrophotometric Simultaneous Determination of Paracetamol and Ibuprofen in Combined Tablets by Derivative and Wavelet Transforms. The Scientific World Journal 2014, 313609.

[4] Easwaramoorthy D, Yu Y \& Huang H (2001), Chemiluminescence detection of paracetamol by a luminol-permanganate based reaction. Analytica Chimica Acta 439, pp. 95. https://doi.org/10.1016/S00032670(01)00968-0.

[5] Shockcor JP, Unger SE, Wilson ID, Foxall PJD, Nicholson JK \& Lindon JC (1996), Combined HPLC, NMR Spectroscopy, and IonTrap Mass Spectrometry with Application to the Detection and Characterization of Xenobiotic and Endogenous Metabolites in Human Urine. Analytical Chemistry 68(24), 4431 - 4435. https://doi.org/10.1021/ac9606463.

[6] Heitmeier S \& Blaschke G (1999), direct determination of paracetamol and its metabolites in urine and serum by capillary electrophoresis with ultraviolet and mass spectrometric detection. Journal of Chromatography B 721(1), 93 - 108. https://doi.org/10.1016/S03784347(98)00415-0.

[7] European Pharmacopoeia (1997), Convention on the Elaboration of a European Pharmacopoeia, third edition. European Treaty. 50, 748 749.

[8] Kumar KG \& Letha R (1997), Determination of paracetamol in pure form and in dosage forms using N, N-dibromo dimethylhydantoin. Journal of Pharmaceutical and Biomedical Analysis 15, 1725-1728. https://doi.org/10.1016/S0731-7085(96)01976-0.

[9] British Pharmacopoeia CD, (1998), Version 2, the Stationery Office Ltd., Norwich.

[10] Usifoh CO, Adelusi SA \& Adebamco RF (2002), Colorimetric determination of paracetamol in raw material and in pharmaceutica dosage forms Pak. Journal of Scientific and Industrial Research 45(1), $7-9$.

[11] Issa MM, Najem RM, El-Abadla NS, Alkholy M \& Akila AS (2008), Novel Atomic Absorption Spectrometric and Rapid Spectrophotometric Methods for the Quantitation of Paracetamol in Saliva: Application to Pharmacokinetic Studies. Indian Journal of Pharmaceuti cal Sciences, 70 (3), 344-350. https://doi.org/10.4103/0250474X.42999.

[12] Silva MLS, Garcia MBQ, Lima JLFC \& Barrado E (2005), Flow System with electrochemical detection for determination of paracetamol in pharmaceutical preparations. Port Electrochimica Acta 24 261-271. https://doi.org/10.4152/pea.200602261.

[13] Suzen S, Cernal A, Senol T, Serder ER, Atilla O \& Semsating C (1998), Quantitation of acetaminophen in pharmaceutical formulations using High Performance Liquid Chromatography. Journal of Faculty of Pharmacy of Ankara, 27(2), 93 - 100.

[14] Vilchez JL, Blanc R, Avidad R \& Navalon A (1995), Spectrofluorometric determination of paracetamol in pharmaceuticals and biological fluids. Journal of Pharmaceutical and Biomedical Analysis 13(9), 1119 - 1125. https://doi.org/10.1016/0731-7085(95)01537-U.

[15] Mohamed FA, AbdAllah MA \& Shannat SM (1997), Selective spec trophotometric determination of p-aminophenol and acetaminophen Talanta 44, 61 - 68. https://doi.org/10.1016/S0039-9140(96)020139.

[16] Criado A, Cárdenas S, Gallego M \& Valcárcel M (2000), Continuous flow spectrophotometric determination of paracetamol in pharmaceuticals following continuous microwave assisted alkaline hydrolysis. Talanta 53, 417-423. https://doi.org/10.1016/S00399140(00)00509-9.

[17] Criado A, Cárdenas S, Gallego M, Valcárcel M (2000), Fast urinary screening for paracetamol using on-line microwave assisted hydrolysis and spectrophotometric detection. Analyst 125, 1179 - 1183 https://doi.org/10.1039/b001153n.

[18] Rodenas V, Garc'ia MS, Sánchez-Pedreo C \& Albero MI (2000), Simultaneous determination of propacetamol and paracetamol by derivative spectrophotometry. Talanta 52(3), 517 - 523. https://doi.org/10.1016/S0039-9140(00)00397-0.

[19] Ruiz-Medina A, Fernández-de córdova ML, Ayora-Ca`nada MJ, Pascual-Reguera MI \& Molina-Diaz A (2000), A flow-through solid phase UV spectrophotometric biparameter sensor for the sequential determination of ascorbic acid and paracetamol. Analytica Chimica Acta 404(1), 131 - 139. https://doi.org/10.1016/S00032670(99)00693-5.

[20] Fatibello-Filho O \& Vieira HJ (2008), Spectrophotometric flow injection procedure to indirect determination of paracetamol in pharmaceutical formulations using O-tilidine as reagent. Ecletica Quimica 33(2), 47 - 54. https://doi.org/10.1590/S010046702008000200007
[21] Pavan Kumar GVSR, Bhuvan Kumar G, Chandra Sekhar T \& Murthy BS (2012), Spectrophotometric Determination of Paracetamol Using Sodium bismuthate as Chromogen. International Journal of Research in Chemistry and Environment 2(1), 231-235.

[22] Sharma SK, Barot GBD \& Multani PJ (2013), Development and validation of vierdot's and q-ratio method for the estimation of paracetamol, domperidone and flunarizine in solid oral dosage form. International Journal of Pharmacy and Pharmaceutical Sciences 5(2), 347-351.

[23] Dubey N, Jain D \& Jadhawani S (2012), Stability-indicating HPTLC method for simultaneous estimation of famotidine, paracetamol, and ibuprofen in combined tablet dosage forms. Journal of Planar Chromatography - Modern TLC 25 (2), 162-167. https://doi.org/10.1556/JPC.25.2012.2.13.

[24] Yang X, Feng J, Chen Z, Liao R \& Li X (2012), Determination of six analgesics by $\mathrm{CE}$ with an improved electromagnetic induction

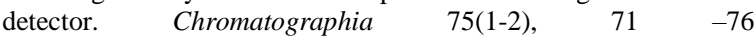
https://doi.org/10.1007/s10337-011-2151-y.

[25] Baptistao M, Rocha WFC \& Poppi RJ (2011), Quality control of the paracetamol drug by chemometrics and imaging spectroscopy in the near infrared region. Journal of Molecular Structure 1002, 167-171. https://doi.org/10.1016/j.molstruc.2011.07.019.

[26] Marcelo MS \& Ronei (2004), N-way PLS applied to Simultaneous Determination of acetylsalicylic acid, Paracetamol and caffeine. Journal of Pharmaceutical and Biomedical Analysis 34(1), 27 - 34 https://doi.org/10.1016/j.japna.2003.08.011.

[27] Wefaa SH (2008), Determination of Ibuprofen and paracetamol in binary mixture using chemometric assisted spectrophotometric methods. American Journal of applied sciences 5(8), 1005-1012. https://doi.org/10.3844/ajassp.2008.1005.1012.

[28] Issa YM, Zayed SIM \& Habib IHI (2011), Simultaneous determination of ibuprofen and paracetamol using derivatives of the ratio spectra method. Arabian Journal of Chemistry B (3), 259-263. https://doi.org/10.1016/j.arabjc.2010.06.044.

[29] Buddha RS \& Raja RP (2009), Spectrophotometric method for the determination of Paracetamol Journal of Nepal Chemical Society 24

[30] Xu C \& Li B (2004), Spectrophotometric determination of paracetamol with microwave assisted alkaline hydrolysis. Spectrochimica Acta. Part A. Molecular and Biomolecular Spectroscopy 60, 186 https://doi.org/10.1016/j.saa.2003.10.003.

[31] Islam,SMA, Abuzar SM \& Paul PK (2011), Validation of UV Spectrophotometric and RP-HPLC methods for the simultaneous analysis of Pracetamol and Acelofenac in marketed tablets. International Journal of Pharmacy and Life Sciences 12, 1267 -1275.

[32] Entidhar JAA, Lalaa AAR, Adnan AB, Nawzat DAJ \& Nidal AQ (2012), Development and validation of a sensitive and accurate method for determination of atorvastatin and rosuvastatin in rat plasma by reversed - phase high performance liquid chromatography with UV detection. International Journal of Pharmacy and Pharmaceutical Sciences 5(2), 211-219.

[33] Cekic SD, Filik H \& Apak R (2005), Simultaneous Spectrophotometric Determination of Paracetamol and $\mathrm{P}$-aminophenol in pharmaceutical products with Tiron using dissolved oxygen as oxidant Journal analytical chemistry 60(11), 1019-1023. https://doi.org/10.1007/s10809-005-0230-7. 